\title{
The Obligation to Cooperate in the Fight against Climate Change
}

\author{
Jason Rudall | ORCID: 0000-0003-2722-8964 \\ Assistant Professor of Public International Law, Grotius Centre for \\ International Legal Studies, Leiden University, Leiden, The Netherlands \\ j.t.p.rudall@law.leidenuniv.nl
}

\begin{abstract}
Cooperation has a relatively long history under international law. This duty is evident in and has been developed by a variety of international instruments as well as the jurisprudence of courts and tribunals, treaty-bodies and other international institutions. This article examines cooperation as it pertains to climate governance. It appraises the current and emerging dimensions of cooperation, the relationship with other obligations, principles and concepts in this area, as well as asking which aspects of cooperation must be ameliorated to better serve the fight against climate change.
\end{abstract}

\section{Keywords}

cooperation - climate change - international law - Paris Agreement - human rights international dispute settlement

Introduction

Cooperation is central in tackling the threat posed by climate change. The effects of climate change will be felt by all states and combating climate change requires the efforts of every state. At the same time, not all states have the resources to take the necessary measures to mitigate or adapt to the effects of climate change, while other states have the resources to do more in the fight against this common global challenge. Cooperation can help to bridge this gap.

The 2030 Agenda for Sustainable Development explicitly recognises the centrality of cooperation to climate change action, setting out that 
' $[t]$ he global nature of climate change calls for the widest possible international co-operation aimed at accelerating the reduction of global greenhouse gas emissions and addressing adaptation to the adverse impacts of climate change.'. Similarly, United Nations Secretary-General Antonio Guterres has noted the alarming pace of climate change and warned that if the world does not come together, there is a risk that climate change will be irreversible. ${ }^{2}$ His predecessor, Ban Ki-moon, observed that recent developments in climate change governance were a reflection of 'the urgency for action, and ... the consensus of governments that robust global cooperation is essential to meet the climate challenge.. ${ }^{3}$ The need for swift action has only been confirmed by the findings of the Intergovernmental Panel on Climate Change, which has called for immediate efforts to ensure that global warming does not exceed 1.5 degrees Celsius. ${ }^{4}$

The duty to cooperate is evident in a wide range of international instruments as well as the jurisprudence of courts and tribunals, treaty-bodies and various other international institutions. Indeed, under international law cooperation finds application in many different fora, including peace and security, human rights, economic relations, and others. ${ }^{5}$ This article examines cooperation as it pertains to the legal framework governing climate change. It appraises the current and emerging dimensions of cooperation, the relationship with other obligations, principles and concepts in this area, as well as asking which aspects of cooperation must be ameliorated to better serve the fight against climate change.

Cooperation and Its Architecture in Climate Change Governance

In the international climate change regime, cooperation is referred to in all three of the principal governing instruments. The 1992 United Nations Framework Convention on Climate Change (UNFCCC) ${ }^{6}$ refers to coopera-

1 Transforming our world: The 2030 Agenda for Sustainable Development, UN Doc. A/RES $/ 70 / 1,21$ October 2015, para 31.

2 ввС News, 'Climate change moving faster than we are, says UN Secretary General', 10 September 2018, available at https://www.bbc.com/news/science-environment-45471410.

3 United Nations Secretary-General, Statement by the Secretary-General on the Paris Agreement on Climate Change, 5 October 2016, https://www.un.org/sg/en/content/sg/statement/ 2016-10-05/statement-secretary-general-paris-agreement-climate-change.

4 Intergovernmental Panel on Climate Change, 'Special Report: Global Warming of ${ }_{1.5} \mathrm{C}$ ', October 2018, https://www.ipcc.ch/sri5/.

5 See Laurence Boisson de Chazournes and Jason Rudall, "Co-operation", in Jorge E. Viñuales (ed), The UN Friendly Relations Declaration at 50 (2020).

6 UN Framework Convention on Climate Change 1992 (UNFCCC), 1771 UNTS 107. 
tion in several provisions, including its Preamble as well as Articles 3, 4, 5, 6, 7 and 9. The $1997 \mathrm{Kyoto}$ Protocol $^{7}$ made reference to international cooperation in its Articles 2, 10, and 13, and the 2015 Paris Agreement ${ }^{8}$ refers to it in its Preamble, Articles 6, 7, 8, 10, 11, 12 and 14. As is evident from its provision in these instruments, cooperation between states and other actors should play a critical and multidimensional role in tackling the various challenges presented by climate change. Beyond the broad appeal to cooperation in the abstract, these instruments also give real meaning to the duty. A closer look at several provisions reveals the specific action that is required.

A cornerstone of the most recent of these instruments - the Paris Agreement - is the so-called nationally determined contributions (NDCs), which comprise the commitments states make themselves and for themselves in the climate change regime. Like the UNFCCC, the Paris Agreement is based on the advancement of a common interest. It recalls that 'climate change is a common concern of humankind'9 which requires the action of all states in both individual and collective ways. The NDCs will rely on international cooperation for their effectiveness as states must strive to be as ambitious as they can in reducing their own greenhouse gas emissions, but also in the support they provide to other states.

Article 6 of the Paris Agreement is squarely concerned with international cooperation. Under Article 6, provision is made for voluntary cooperation among Parties so that more ambitious NDCs may be set. This applies to both mitigation and adaptation commitments made by states. In particular, voluntary cooperation that concerns internationally transferred emissions reductions and which promotes sustainable development is encouraged. Parties may cooperate bilaterally in accordance with Article 6(2) so that emission reductions may be achieved in one state and transferred to another state. In this context, it is important that emission reductions are not counted twice and, as such, transparency and robust accounting has a role to play. Similarly, Article 7 of the Paris Agreement is concerned with adaptation and it foresees a role for cooperation in strengthening national adaptation efforts.

Cooperation also has a special function in helping to promote equity among states in climate governance. According to Article 3(1) UNFCCC, developed countries should 'take the lead in combating climate change and the adverse effects thereof'. Both the UNFCCC and the Paris Agreement provide that developed countries must facilitate capacity building, offer financial support and transfer technology to developing countries so that those developing countries

7 Kyoto Protocol to the UNFCCC, 2303 UNTS 162, 11 December 1997.

8 Paris Agreement, FCCC/CP/2015/10/Add.1, 12 December 2015.

9 ibid, Preamble, para 11. 
can fulfil their obligations. ${ }^{10}$ The Paris Agreement envisages cooperation in technology development and transfer under its Article 10. Moreover, the Agreement requires developed and developing countries to 'strengthen cooperative action on technology development and transfer."1 Developed countries are also expected to help developing countries with the costs of adaptation to the effects of climate change. ${ }^{12}$

Under the Paris Agreement, developed countries should declare how they are assisting developing countries. ${ }^{13}$ In accordance with the principle of common but differentiated responsibilities, developed states have committed to approximately 100 billion dollars per year and there is a further undertaking to set new financial assistance objectives periodically. ${ }^{14}$ The Paris Agreement also aims to ensure that there is 'efficient access to financial resources through simplified approval procedures and enhanced readiness support for developing country Parties. ${ }^{15}$ Several countries have in fact revised their commitments to the Adaptation Fund..$^{16}$ Moreover, Germany and Norway said they would double their contribution to the Green Climate Fund. ${ }^{17}$ These commitments all represent manifestations of cooperation in the climate change regime, and are examples of cooperation as it might be traditionally conceived, that is as commitments by some countries to help others in dealing with a mutual problem.

Beyond the pursuit of more equitable burden-sharing, cooperation has other functions under the climate change regime. Indeed, Article 12 of the Paris Agreement provides for cooperative efforts around climate change education, awareness, public participation and public access to information. This is an example of a provision where developed countries are obliged to engage in cooperation on particular matters rather than achieve a pre-defined result. ${ }^{18}$ And so specific roles for cooperation have been explicitly carved out under the

10 See, for example, Article 4(1)(c), 4(3), and 4(5) of the UnfCcc; Article 9(1) of the Paris Agreement.

11 Article 10(2) of the Paris Agreement.

12 See, for example, Article 4(4) of the UNFCCC.

13 Article 13(9) of the Paris Agreement.

14 Decision of the Contracting Parties, FCCC/CP/2015/10/Add.1, 12 December 2015, para Paragraph 54 .

15 Article 9(9) of the Paris Agreement.

16 For example, Germany, Sweden, Italy, France, Belgium and the European Union. See Adaptation Fund, 'Adaptation Fund Breaks Single-Year Resource Mobilization Record with Nearly US\$ $129 \mathrm{M}$ in New Pledges Received', 12 December 2018, https://www .adaptation-fund.org/adaptation-fund-breaks-single-year-resource-mobilization-record -nearly-us-129m-new-pledges-received/.

17 See Green Climate Fund, 'GCF replenishment wins strong endorsement at COP24', 13 December 2018, https://www.greenclimate.fund/news/gcf-replenishment-wins-strong -endorsement-at-cop24.

18 See, for example, Article 4(1)(c), 4(1)(e) and 4(1)(h) of the UNFCCC. 
main instruments dealing with climate change. But other manifestations of cooperation may also have relevance for state action in this battle.

A duty to cooperate can in fact be found across international environmental law. ${ }^{19}$ It can imply, for example, the exchange of information between states, the conduct of scientific research and systematic observations, prior notification, consultation, prior informed consent, notification in the case of an emergency or emergency assistance. There is also provision made for cooperation in investigating, identifying, and avoiding environmental harm. Such specific duties have been developed from the earliest instruments of the contemporary system of environmental governance, such as the Stockholm and Rio Declarations, which provide for cooperation between states as well as sectors and different private actors to achieve environmental objectives. ${ }^{20}$

International courts and tribunals have also played an important role in elaborating the content of the duty to cooperate in the context of environmental protection, as well as connecting it with other duties under international environmental law. Indeed, they have found that cooperation can require states to consult with the secretariat of an environmental treaty, exchange information, or conduct a joint environmental impact assessment of a given activity. ${ }^{21}$ They have also noted that notification and consultation are further dimensions of the duty to cooperate. ${ }^{22}$ The International Court of Justice (ICJ) has said that 'the obligation to inform ... allows for the initiation of cooperation between the Parties which is necessary in order to fulfil the obligation of prevention'. ${ }^{23}$ In other cases, the ICJ has observed that parties should cooperate to avoid hampering the socio-economic activities of local communities who inhabit a given area ${ }^{24}$ while the International Tribunal for the Law of the

19 For a detailed consideration, see Laurence Boisson de Chazournes and Jason Rudall, "Cooperation in a Transboundary and Global Context" in Yann Aguila and Jorge E. Viñuales (eds), A Global Pact for the Environment: Legal Foundations (2019).

20 See, for example, Principle 24 of the United Nations Stockholm Declaration on the Human Environment, UN Doc. A/RES/2994, 15 December 1972 and Preamble and Principle 27 of the Rio Declaration on Environment and Development, UN Doc. A/CONF.151/26, 12 August 1992.

21 See, for example, Certain Activities Carried Out by Nicaragua in the Border Area (Costa Rica v. Nicaragua), Provisional Measures, Order of 8 March 2011 [2011] ICJ Reports 6; MOX Plant Case (Ireland v. United Kingdom), Provisional Measures, IT Los Case 10, 3 December 2001, para 89; Fisheries Jurisdiction (UK v. Iceland), Judgment [1974] ICJ Reports 3, para 72.

22 Pulp Mills on the River Uruguay (Argentina v. Uruguay), Judgment [2010] ICJ Reports 14, para 77 .

23 ibid, para 102.

24 Case Concerning the Kasikili/Sedudu Island (Botswana v. Namibia), Judgment [1999] ICJ Reports 1045. See also Laurence Boisson de Chazournes, 'The Uses of International Watercourses and Equity' in Agua, recurso natural limitado: Entre el desarrollo sostenible y la seguridad internacional (Marcial Pons, 2018), 41-54. 
Sea has noted that ' $\mathrm{t}$ ] he duty to cooperate is a fundamental principle in the prevention of pollution of the marine environment ....25 Over time, the duty to cooperate has evolved into a range of specific obligations under international environmental law. These undoubtedly shape what is required of states in their efforts to combat climate change as well as in their responses to the particular challenges that the effects of climate change will create in the future.

In 2014, the International Law Association adopted its Draft Articles on Legal Principles Relating to Climate Change, which encapsulate the 'foundational legal principles relating to climate change as well as to their inter-relationship' and are intended to guide states in their response to climate change. ${ }^{26}$ These were arrived at following an analysis of jurisprudence, international treaties and state practice. ${ }^{27}$ Draft Article 8 deals with international cooperation. As well as calling for general cooperation between states, and between states and international organisations, the provision also sets out more specific forms of cooperation. These include cooperation to assist developing countries and others where their capacity to respond to climate disasters is exceeded, to enhance scientific knowledge, to develop emission reduction standards, to adopt new legal frameworks and to ensure the adequacy of international law in dealing with the threat of climate change. ${ }^{28}$ The emergence of the innovative regime under the Paris Agreement shows what can be achieved when states act together in the spirit of these principles.

While the obligation to cooperate has a long history under international law, ${ }^{29}$ its application in the context of climate change governance is relatively recent. That said, as the above illustrates, cooperation is beginning to acquire particular meaning in this emerging context. It thus has specific functions and implies both obligations and rights for states. It can oblige states to act collectively to develop the climate change regime as well as place individual states under a responsibility to mitigate emissions and adapt to the new realities that climate change induces. Further still, cooperation impels developed countries to provide assistance for developing countries that do not have the

25 MOX Plant Case (Ireland v. United Kingdom), Provisional Measures, ITLOS Case No. 10, 3 December 2001, para 82.

26 ILA, Declaration of Legal Principles Relating to Climate Change, Resolution 2/2014, Annex: Draft Articles on Legal Principles Relating to Climate Change, April 2014, Draft Article 1.

27 Christoph Schwarte and Will Frank, “The International Law Association's Legal Principles on Climate Change and Climate Liability Under Public International Law" 4(3-4) Climate Law (2014) pp. 201-216, 202.

28 ILA, Declaration of Legal Principles Relating to Climate Change, op. cit., Draft Article 8.

29 See Boisson de Chazournes and Rudall, 'Co-operation', op. cit. 
resources to meet their mitigation and adaptation responsibilities. It is in this way that cooperation acts in consort with and is shaped by other principles of international environmental law, like the principle of common but differentiated responsibility.

As hinted at, there are new forms of cooperation emerging, and these are particularly evident in the climate change regime because of the particular consequences that climate change presents. We now turn to focus on several examples of those new dimensions of cooperation.

Cooperation and Its New Dimensions in Climate Change Governance

Cooperation is also finding new roles and relationships as the challenges of and legal regime around climate change evolve. An example is the way transparency and accountability are becoming important tools for the implementation of cooperation. ${ }^{30}$ Transparency under the Paris Agreement means that an array of new actors have easy access to information online. Non-governmental organizations, scientific associations and other actors may take advantage of these new tools in advocating for change. This transparency and accountability to civil society could indeed provide a renewed impetus for states to cooperate to realise their commitments in tackling climate change.

Article 13 of the Paris Agreement envisages an 'enhanced transparency framework for action and support'. This includes an augmented reporting mechanism that is concerned with the action and support of states. Developed countries are expected to report on financial assistance, technology transfer and capacity building support provided to developing country parties under Articles 9, 10 and 11 of the Paris Agreement. This information provided by developed countries will also be subject to a technical expert review. In addition, interestingly, developing countries should report on financial assistance, technology transfer and capacity building support needed and received. Greater transparency was also envisaged through the Katowice Rulebook in the context of funding for developing countries. ${ }^{31}$ This suggests that cooperation is being institutionalized through the elaboration of specific mechanisms and processes to assist in the implementation of the Paris Agreement.

$30 \quad$ ibid.

31 Report of the Conference of the Parties on its twenty-fourth session, held in Katowice from 2 to 5 December 2018, Decision 1/CP.24, FCCC/CP/2018/10/Add.1, 19 March 2019. 
As is becoming clear, the climate change regime is beginning to create institutional machinery around the appraisal of cooperative efforts. ${ }^{32}$ Another good example of the emerging institutionalization of cooperation in the climate change regime is provided by Article 6(4) of the Paris Agreement, which sets in motion the creation of a new sustainable development mechanism. This mechanism is intended to support the mitigation of greenhouse gas emissions as well as promote sustainable development more generally. This would be a mechanism supervised by the Conference of Parties (COP), which will also adopt the rules, modalities and procedures for the mechanism. Similarly to the provision on bilateral cooperation, cooperation through this mechanism envisages that any emission reductions could be transferred from one country to another, and in turn would count toward the latter's NDCs. Moreover, as with the bilateral process, the ambition is to reduce net global greenhouse gas emissions.

In a different way, the Warsaw International Mechanism for Loss and Damage associated with Climate Change Impacts is a non-contentious mechanism for addressing the impacts of climate change. This mechanism came into being at COP 19 of the UNFCCC and was incorporated into the Paris Agreement at COP 21. ${ }^{33}$ It does not seek to repair past damage nor attribute liability. ${ }^{34}$ Rather, the Warsaw Mechanism is future facing and cooperative in its approach. In order to fulfil its function, the Warsaw Mechanism is tasked with 'promoting the implementation of approaches to loss and damage associated with the effects of climate change' by, inter alia, 'fostering dialogue, coordination, coherence and synergies among all relevant stakeholders, institutions, bodies, processes and initiatives outside the [UNFCCC] with a view to promoting cooperation and collaboration across relevant work and activities at all levels. ${ }^{35}$ Furthermore, parties are invited to develop institutions or networks at various levels to ensure that loss and damage is dealt with appropriately, particularly in developing countries, as well as to promote cooperation between different stakeholders.

In appraising loss and damage, as well as the cooperative action required to address it, states must recognize that significant intangible harm is likely

32 Boisson de Chazournes and Rudall, "Cooperation in a Transboundary and Global Context", op. cit., 149-156.

33 See UNFCCC Decision 2/CP.19: Warsaw International Mechanism for Loss and Damage Associated with Climate Change Impacts, 2013; UN FCCC Adoption of the Paris Agreement FCCC/CP/2015/10/Add.1.1_32, 2015.

34 Decision of the Contracting Parties, para 52.

35 Warsaw International Mechanism on Loss and Damage, UN Doc. FCCC/CP/2013/10/ Add.1, para 5. 
to result from climate change, in addition to tangible economic harm. Indeed, techniques of valuation should reflect non-economic, inherent, or intrinsic value that has been lost as well. ${ }^{36}$ Climate-related harm is likely to result from floods, droughts, increased temperature and heat waves, storms, sea level rises, glacial melting, reduced sea ice, as well as bush, forest and wildfires. ${ }^{37}$ This can lead to the deprivation of culture, lifestyles, traditions and heritage, among many other elements that are central to peoples' lives. ${ }^{38}$

If states do not take action that is ambitious enough, climate change will have many devastating effects. One of these will be the displacement of peoples as their homelands become unhabitable. In this context too, cooperation will have a role to play across different legal regimes. International refugee law and the Global Compact on Refugees - the latter adopted in 2018 - set out the concrete obligations on states and help to define the arrangements for burdenand responsibility-sharing. The Convention relating to the Status of Refugees of $195^{1}$ makes explicit that international cooperation is critical to alleviating refugee crises, not least because certain countries may face unduly heavy burdens. ${ }^{39}$ The Global Compact on Refugees similarly emphasizes the centrality of cooperation. ${ }^{40}$ In fact, the latter creates a periodic Global Refugee Forum, which represents a ' $\mathrm{g}] \mathrm{lobal}$ arrangement for international cooperation' and includes mechanisms for states to make pledges and contributions in the areas of financial, material and technical assistance. ${ }^{41}$ Under this regime, cooperation is envisaged between states, between states and international organisations like the Office of the United Nations High Commissioner for Refugees, as well as between states and private actors like donors.

The fruits of certain state efforts in the area of human displacement can be observed. Some concrete measures have been adopted by states as a result of calls for cooperation from instruments like the Cancún Adaptation Framework, which provides that states should take ' $[\mathrm{m}]$ easures to enhance understanding, coordination and cooperation with regard to climate change induced displacement, migration and planned relocation, where appropriate, at the

36 For a detailed analysis of these concepts, see Jason Rudall, Compensation for Environmental Damage Under International Law (2020).

37 See Petra Tschakert, Neville Ellis, Christopher Anderson, A. Kelly, and James Obeng, 'One thousand ways to experience loss: A systematic analysis of climate-related intangible harm from around the world' 55 Global Environmental Change (2019) pp. 58, 6 o.

38 ibid, p. 62 .

39 Preamble of the Convention relating to the Status of Refugees 1951, 189 UNTS 2545.

40 Global Compact on Refugees, adopted by General Assembly Resolution A/RES/73/151, 17 December 2018.

41 ibid, paras 17-19. The first Global Refugee Forum took place in December 2019. For more information, see https://www.unhcr.org/programme-and-practical-information.html. 
national, regional and international levels.42 Similarly, the International Law Commission's (ILC) Draft Articles on the Protection of Persons in the Event of Disasters provide guidance and set out that ' $[\mathrm{e}] \mathrm{ffective}$ international cooperation is indispensable for the protection of persons in the event of disasters.' ${ }^{43}$ Draft Article 8 notes that 'forms of cooperation' could extend to 'humanitarian assistance, coordination of international relief actions and communications, and making available relief personnel, equipment and goods, and scientific, medical and technical resources'. Further still, the ILC's Commentary on Draft Article 8 describes that cooperation could include 'financial support; technology transfer covering, among others, technology relating to satellite imagery; training; information-sharing; joint simulation exercises and planning; and undertaking needs assessments and situation overview'.44 And in the spirit of these provisions, some states have strengthened the resilience of their infrastructure to natural disasters, facilitated the entry of people stranded at borders, assisted with the safe return of peoples, shared best practices and supported capacity building in other states. ${ }^{45}$

Whether these initiatives will be sufficient remains to be seen. That said, all bring new dimensions to the meaning of the duty to cooperate in the fight against climate change, particularly as the concrete problems it presents evolve and worsen. One of the major challenges is the threat climate change poses to fundamental human rights. Cooperation, I suggest, should have an enhanced role to play in this context as well.

\section{Cooperation, Human Rights and Climate Change Governance}

The Office of the High Commissioner for Human Rights has said of international cooperation to combat climate change that it is not only expedient but also a human rights obligation and that its central objective is the realisation

42 Conference of the Parties, UnfCcc, Report of the Conference of the Parties on Its Sixteenth Session, Held in Cancun from 29 November to 10 December 2010 - Addendum Part 2: Action Taken by the Conference of the Parties at Its Sixteenth Session, UN Doc. FCCC/CP/2010/7/Add.1, 15 March 2011, Decision 1/CP.16 [14(f)] (Cancún Adaptation Framework).

43 Draft Articles on the Protection of Persons in the Event of Disasters 2016: with Commentary, UN Doc. A/71/10, 36 .

44 ibid, 41.

45 See, for example, The Nansen Initiative, 'Global Consultation Conference Report: Geneva, 12-13 October', December 2015, https://www.nanseninitiative.org/wp-content/ uploads/2015/o2/GLOBAL-CONSULTATION-REPORT.pdf. 
of human rights.' ${ }^{46}$ Cooperation is thus required to ensure human rights are realised despite the detrimental effects that climate change will wreak. This adds yet another layer to our understanding of cooperation as it is provided for under both climate and human rights law. Cooperation can be found explicitly mentioned in various human rights instruments. A particularly good example of the positive obligations that states are under to cooperate for the realisation of human rights is Article 2(1) of the International Covenant on Economic, Social and Cultural Rights $1966 .{ }^{47}$ Beyond diplomatic efforts at cooperation, this provision also envisages the commitment of resources and assistance. A distinction is made in the text of this article between taking steps 'individually' and 'through international assistance and co-operation'. This is an indication that the Covenant binds states as regards their own citizens but also creates a commitment in respect of citizens of other countries. And so cooperation can have the effect of expanding the reach of human rights protection. ${ }^{48}$

It is my submission that cooperation will play a new role as courts and tribunals similarly extend the scope of human rights obligations that states are under in the context of environmental protection. Indeed, several recent cases emphasise the increasing importance of cooperation, as well as highlight the connection between environmental degradation and the deprivation of human rights. In a significant advisory opinion, the Inter-American Court of Human Rights in its The Environment and Human Rights case ${ }^{49}$ confirmed the link between the realisation of human rights and the existence of a healthy environment. The Court found that States should take measures to ensure significant environmental harm is not caused to individuals within or beyond their territory. ${ }^{50}$ The Court noted that States have a duty to ensure the rights of persons outside their territory are not impaired..$^{51}$ It thus offers an expanded notion of jurisdiction. In this respect, a stronger argument can now be made that greenhouse gases emitted by a State could lead to the attribution of responsibility for damage caused to people in other States and it has been said that this case contributes to the evolving case law on 'cross border

46 Office of the High Commissioner for Human Rights, The Relationship between Climate Change and Human Rights, UN Doc. A/HRC/10/61, 15 January 2009, 30.

47 International Covenant on Economic, Social and Cultural Rights 1966, 993 UNTs 3.

48 For further discussion of this provision, see Jason Rudall, Altruism in International Law (2021), chapter 3 .

49 The Environment and Human Rights (State obligations in relation to the environment in the context of the protection and guarantee of the rights to life and to personal integrity - interpretation and scope of Articles $4(1)$ and 5(1) of the American Convention on Human Rights), IACt.HR Advisory Opinion OC-23/17, Series A No. 23, 15 November 2017.

$5^{\circ} \quad$ ibid.

$5^{1} \quad$ ibid, paras 81, 95 and 101. 
human rights claims arising from transboundary environmental impacts.' ${ }^{52}$ Cooperation will be needed to ensure contiguous human rights protection in such a context.

There has also been a steady increase in litigation on the climate in domestic jurisdictions. ${ }^{53}$ These cases have been brought on various bases. In the Netherlands, Dutch courts have recently ordered the government to reduce emissions so that its citizens may be protected from climate change. ${ }^{54}$ Notably, the courts said the Dutch government must be more ambitious in its emission reduction targets. They warned that the threat posed by global warming is acute, and that the Dutch government had committed to act through international treaties. One judge noted specifically that the state should not hide behind the argument that the solution to the global climate problem does not depend solely on Dutch efforts. ${ }^{55}$ And so cooperation can be a sword for pushing individual states to do more in their contributions to the common challenge of climate change, rather than a shield that states can hide behind to evade responsibility.

It will be interesting to see whether this climate litigation has an influence on the development of cooperation in other ways or if it provides an impetus for states to cooperate in more meaningful senses to meet the demands of a changing climate. It has already helped to highlight the relationship between human rights and the environment, which may put pressure on governments to pursue policies that recognize and address the far-reaching consequences of climate change. ${ }^{56}$ Indeed, many different human rights are affected by climate change, not just the emerging right to a healthy environment. It is for this reason that cooperation, human rights and climate governance go hand-in-hand. States should cooperate to ensure human rights are universally realized in the context of a deteriorating climate. Moreover, even if climate change treaties themselves do not refer directly to human rights, recourse to systemic interpretation that recognizes the impact of climate change on human rights should be part of any interpretative endeavours involving such treaties.

52 Monica Feria-Tinta and Simon Milnes, "The Rise of Environmental Law in International Dispute Resolution: Inter-American Court of Human Rights issues Advisory Opinion on Environment and Human Rights' 27 Yearbook of International Environmental Law (2016) p. 64 .

53 For a good overview, see United Nations Environment Programme, 'The Status of Climate Litigation: A Global Review' (2017).

54 The Netherlands $v$. Urgenda, No. 200.178.245/o1 (2018). The case was upheld by the Hague Court of Appeal on 9 October 2018 and the Dutch Supreme Court on 13 January 2020 (The Netherlands v. Urgenda, No. 19/0o135).

55 The Netherlands v. Urgenda, No. 200.178.245/o1 (2018).

56 See Margaretha Wewerinke-Singh, State Responsibility, Climate Change and Human Rights under International Law (2019). 


\section{$5 \quad$ Concluding Remarks}

Cooperation is an essential principle of international law, ${ }^{57}$ and it is playing an increasingly important role in climate change governance. It is multifaceted and manifested in a variety of ways in the UNFCCC, the Kyoto Protocol and the Paris Agreement. The latter has helped to define the contours of cooperation in terms of the obligations borne by developed countries towards developing countries in respect of climate change mitigation and adaptation, as well as institutionalizing the obligation of cooperation in important ways. Outside of these institutional contexts, the long-standing obligation to cooperate should also compel individual action to help with the fight against climate change. This can include shaping and following new international environmental law principles, helping those displaced, and ensuring that human rights are not infringed by the effects of climate change, as well as ensuring that transgressors are brought into compliance.

No one single state can solve climate change and all states will be affected in one way or another by it. Cooperative action is perhaps our best shot at tackling the monumental challenge at hand. This is why the task of giving it concrete meaning that translates into specific obligations is critical and should continue. Much has been achieved in this context, but there is much more to do. Given the nature and scale of the climate change threat, the future of the world as we know it may well depend on cooperation.

57 See Boisson de Chazournes and Rudall, 'Co-operation', op. cit. 